J. Clin. Chem. Clin. Biochem.

Vol. 28, 1990, pp. 923-928

(C) 1990 Walter de Gruyter \& Co. Berlin · New York

\title{
The Effect of Pretreatment of Saliva on Steroid Hormone Concentrations
}

\author{
By Eline P. M. M. Meulenberg ${ }^{1}$ and J. A. Hofman ${ }^{2}$ \\ ${ }^{1}$ Laboratorium Experimentele en Chemische Endocrinologie, St. Radboud Ziekenhuis, Nijmegen, \\ The Netherlands \\ 2 Immuno Technology Service B.V., Wychen, The Netherlands
}

(Received March 5/August 7, 1990)

Summary: We investigated the effect of the pretreatment (sonification or centrifugation) of saliva samples on the concentration of several steroid hormones as measured with highly specific RIA after extraction and chromatography. It appeared that sonification of saliva resulted in significantly higher values for progesterone, cortisone, 17-hydroxyprogesterone, testosterone and oestradiol (10-49\% increase), compared with the levels recorded after centrifugation. No differences were demonstrated for the concentrations of cortisol and androstenedione, except that a sex-dependent difference effect was observed in the values for androstenedione: concentrations measured in sonificated male saliva were lower than those measured in supernatant saliva.

\section{Introduction}

Hitherto, the rationale of steroid assays in saliva was based on several assumptions:

1. that the plasma free, protein-unbound, apolar steroid hormones freely diffuse through the salivary gland,

2. that the concentrations of these steroids in saliva are comparable to their plasma free levels,

3. that steroid binding proteins are absent from saliva $(1,2)$.

Indeed, many authors report a very close relationship between the plasma free and salivary concentrations of several endogenous steroids, synthetic steroids and even drugs $(3-9)$. The very fast (infusion-studies) and flow rate-independent appearance of apolar steroids in saliva strengthened the idea of an unhampered diffusion from plasma to saliva (10). In those cases where salivary concentrations did not reflect their plasma free levels, or where plasma free and salivary concentrations were quite different, this was explained by assuming the presence of steroid metabolizing enzyme activities in the salivary gland or by methodological imperfection $(11-15)$.
However, it was later demonstrated that steroids in saliva exist only partly in the unbound state $(4,16-$ $20)$. The assumption that only apolar, lipid-soluble or small polar compounds could enter the saliva by diffusion or ultrafiltration, respectively, had to be reconsidered when several plasma proteins were detected in saliva $(21-28)$. The most disturbing finding, which may result in a re-evaluation of the current concepts in salivary steroid assay, is the detection of specific steroid binding proteins in saliva: corticosteroid binding globulin, sex hormone binding globulin, aldosterone binding globulin $(29-32)$. According to Chu \& Ekins (1989), corticosteroid binding globulin in saliva, which is highly dependent on flow-rate, is not merely a contamination, but should be regarded as a secretion product, originating from plasma.

The generally applied technique of saliva preparation before assay is freezing, thawing and centrifugation, which produces a clear, easily pipettable supernatant. Freezing and thawing of saliva, however, results in precipitation of globular proteins (23), whereas centrifugation leads to a considerable loss in protein content (33). If specific steroid binding proteins are present in saliva the preparation of samples before 
assay may greatly influence the results of steroid hormone determinations, especially when direct assays are used. We were interested in whether the method of pretreatment of salivary samples (centrifugation or sonification) would influence the concentrations of several steroid hormones, which were assayed with highly specific RIA after extraction and chromatography.

\section{Materials and Methods}

\section{Subjects}

For this study 111 healthy, non-medicated subjects volunteered for the collection of saliva. The group consisted of 20 men, 17 pregnant women and 74 non-pregnant women, aged 15-60 years.

\section{Sample collection}

Each subject provided a sample of $15-20 \mathrm{ml}$ of saliva. Citric acid grains were applied to the tongue to stimulate flow and the saliva was spat into plastic cups. After sampling, the saliva was immediately frozen and kept at $-20^{\circ} \mathrm{C}$ until analysis.

\section{Sample preparation}

The saliva samples were thawed at room temperature. After thorough mixing, each sample was divided in two portions One portion was centrifuged for 10 minutes at $1500 \mathrm{~g}$, which yielded a clear saliva supernatant. The other portion was sonificated (2 times 30 seconds) with a MSE Soniprep 150 (MSE Scientific Instruments, Manor Royal, Crawley, Sussex, England) and was referred to as whole saliva.

\section{Materials}

Chromatography solvents were of „Baker Analyzed“ grade (J. T. Baker Chemical Co., Phillipsburg, NJ). All other chemicals were analytical grade. The pure steroids were purchased from Steraloids (Sterraloids INC., Wilton, NH). Tritiated cortisol, cortisone, testosterone, progesterone, androstenedione and oestradiol were purchased from New England Nuclear Corp., Boston, MA. Tritiated 17 $\alpha$-hydroxyprogesterone was from Amersham Int. PLC, Amersham, England. The cortisol and cortisone antisera were a gift from Prof. Vecsei, Heidelberg; testosterone antiserum was a gift from Dr. Pratt, Groningen, The Netherlands; progesterone and oestradiol antiserum were from Organon, Oss, The Netherlands; androstenedione antiserum was purchased from Radio Assay Systems Laboratories Inc., Carson, CA; 17-hydroxyprogesterone antiserum was raised in sheep in the endocrinology division. More details are shown in table 1.

\section{Procedures}

Salivary steroid concentration, were measured by RIA after prior extraction and paper chromatography. The methods used have been previously described in detail $(3,6,7,34)$. Aliquots $(3 \mathrm{ml})$ of saliva were incubated with tritiated recovery tracer $( \pm 10000 \mathrm{dpm}$ each), which was used to monitor procedural losses. After extraction of the samples, the dried extracts were applied to Whatman No. 1 paper and chromatographed in the appropriate descending Bush solvent system: Bush B5 toluene/ methanol/water $2: 1: 1(\mathrm{v} / \mathrm{v})$ for cortisol and cortisone; Bush B3 light petroleum $\left(80-110^{\circ} \mathrm{C}\right) /$ toluene/methanol/water 333:167: 400:100 (v/v) for progesterone, testosterone and oestradiol; modified Bush A light petroleum $\left(80-110^{\circ} \mathrm{C}\right) /$ methanol/water $9: 7: 4(\mathrm{v} / \mathrm{v})$ for 17-hydroxyprogesterone and androstenedione. The tritiated hormone areas were located by radioscanning and eluted. The eluates were used for recovery counting and RIA.

The in-house RIA procedures were optimized for the very low concentrations of the steroids in saliva. Dextran-coated charcoal was used for separation of the free and antiserum bound fraction. The analytical variables are summarized in table 2.

\section{Statistics}

For the statistical analysis of the results we used Pearson regression analysis and Wilcoxon signed rank test.

\section{Results}

The results of the determinations of the steroids in whole saliva and in supernatant saliva are presented in table 3. Correlations between concentrations in whole saliva and supernatant saliva were all highly significant.

In order to demonstrate differences between the concentrations of the several steroid hormones in whole saliva and supernatant saliva, we calculated for each subject the relative increase after sonification of the samples (supernatant saliva $=100 \%$ ). These data are shown in table 4.

It appeared that sonification of saliva samples resulted in a statistically significant increase in concentrations of the steroid hormones, with the exception of cortisol and androstenedione. Our study group, however, was quite heterogeneous. The subjects were divided into pregnant women, non-pregnant women and men. In the pregnant group the results for progesterone and

Tab. 1. Tracers and antisera: $\mathrm{HS}=$ hemisuccinate, CET = carboxy-ethyl-thioether, $\mathrm{CME}=$ carboxy-methyl-ether, CMO $=$ carboxy-methyl-oxime, BSA = bovine serum albumin.

\begin{tabular}{lllr}
\hline Tracer & Specific activity & Immunogen & Antiserum titer \\
\hline$\left[1,2,6,7-{ }^{3} \mathrm{H}\right]$ Cortisol & $3.1 \mathrm{MBq} / \mathrm{mmol}$ & Cortisol-21-HS-BSA & 22.500 \\
{$\left[1,2-{ }^{3} \mathrm{H}\right]$ Cortisone } & $1.1 \mathrm{MBq} / \mathrm{mmol}$ & Cortisone-21-HS-BSA & 15000 \\
{$\left[1,2,6,7-{ }^{3} \mathrm{H}\right]$ Testosterone } & $3.8 \mathrm{MBq} / \mathrm{mmol}$ & Testosterone-7 - -CET-BSA & 99000 \\
{$\left[1,2,6,7-{ }^{3} \mathrm{H}\right]$ Progesterone } & $3.3 \mathrm{MBq} / \mathrm{mmol}$ & Progesterone-11-HS-BSA & 862000 \\
{$\left[1,2,6,7-{ }^{3} \mathrm{H}\right]$ Hydroxyprogesterone } & $2.0 \mathrm{MBq} / \mathrm{mmol}$ & 11-Deoxycortisol-21-HS-BSA & 336000 \\
{$\left[1,2,6,7-{ }^{3} \mathrm{H}\right]$ Androstenedione } & $3.1 \mathrm{MBq} / \mathrm{mmol}$ & Androstenedione-19-CME-BSA & 7600 \\
{$\left[1,2,6,7-{ }^{3} \mathrm{H}\right]$ Oestradiol } & $3.8 \mathrm{MBq} / \mathrm{mmol}$ & Oestradiol-6-CMO-BSA & 88000 \\
\hline
\end{tabular}


Tab. 2. Analytical variables: Bush $=$ chromatography system (see Methods); $\% \mathrm{~B}_{\mathrm{o}}=\%$ binding without standard; $\%$ NSB $=$ $\%$ non-specific binding; Blanco = water blank of the assay (pg/tube); Detection limit = detection limit of the assay $\mathrm{pg} /$ tube $\left(3 \mathrm{xSD}\right.$ of the $\mathrm{B}_{\mathrm{o}}$ ); Standards = range of standard curve $(\mathrm{pg} /$ tube); Tracer $=$ tracer used for recovery and RIA

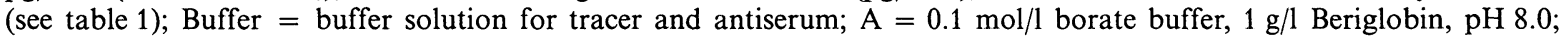
$\mathrm{B}=0.1 \mathrm{~mol} / 1$ borate buffer, $5 \mathrm{~g} / 1$ bovine serum albumin, $\mathrm{pH} 8.0$.

\begin{tabular}{|c|c|c|c|c|c|c|c|}
\hline Steroid & Cortisol & Cortisone & Testosterone & Progesterone & $\begin{array}{l}\text { Hydroxy- } \\
\text { progesterone }\end{array}$ & $\begin{array}{l}\text { Andro- } \\
\text { stenedione }\end{array}$ & Oestradiol \\
\hline Chromatography & Bush B5 & Bush B5 & Bush B3 & Bush B3 & Bush A & Bush A & Bush B3 \\
\hline$\% \mathrm{~B}_{\mathrm{o}}$ & 51 & 37 & 33 & 41 & 38 & 45 & 42 \\
\hline$\%$ NSB & 1.3 & 1.3 & 3.1 & 4.3 & 1.8 & 6.0 & 2.2 \\
\hline Blanco & 2.1 & 1.1 & 0.3 & 5.0 & 5.4 & 3.6 & 1.2 \\
\hline Detection limit & 2.0 & 4.9 & 1.4 & 2.2 & 1.4 & 2.3 & 0.9 \\
\hline$\%$ Recovery & 69 & 69 & 43 & 61 & 56 & 44 & 35 \\
\hline Standards & $10-800$ & $10-800$ & $0.5-200$ & $0.5-200$ & $0.5-200$ & $0.5-200$ & $0.5-200$ \\
\hline Tracer & $4 \times{ }^{3} \mathrm{H}$ & $2 \times{ }^{3} \mathrm{H}$ & $4 \times{ }^{3} \mathrm{H}$ & $4 \times{ }^{3} \mathrm{H}$ & $4 \times{ }^{3} \mathrm{H}$ & $4 \times{ }^{3} \mathrm{H}$ & $4 \times{ }^{3} \mathrm{H}$ \\
\hline Buffer & $\mathrm{A}$ & $\mathrm{A}$ & $\mathrm{B}$ & B & A & A & A \\
\hline Intra-assay $\% \mathrm{CV}$ & 5.9 & 5.2 & 7.1 & 6.7 & 6.3 & 5.0 & 11 \\
\hline Inter-assay $\% \mathrm{CV}$ & 4.9 & 13 & 7.7 & 8.1 & 6.4 & 8.6 & 10 \\
\hline
\end{tabular}

Tab. 3. Concentrations (mean $\pm S E M$ ) of steroids in whole saliva and supernatant saliva: $n=$ number of subjects, $r=$ correlation (Pearson) between individual steroid levels in whole saliva and supernatant saliva assay, ${ }^{*}=\mathrm{p}<0.0001$.

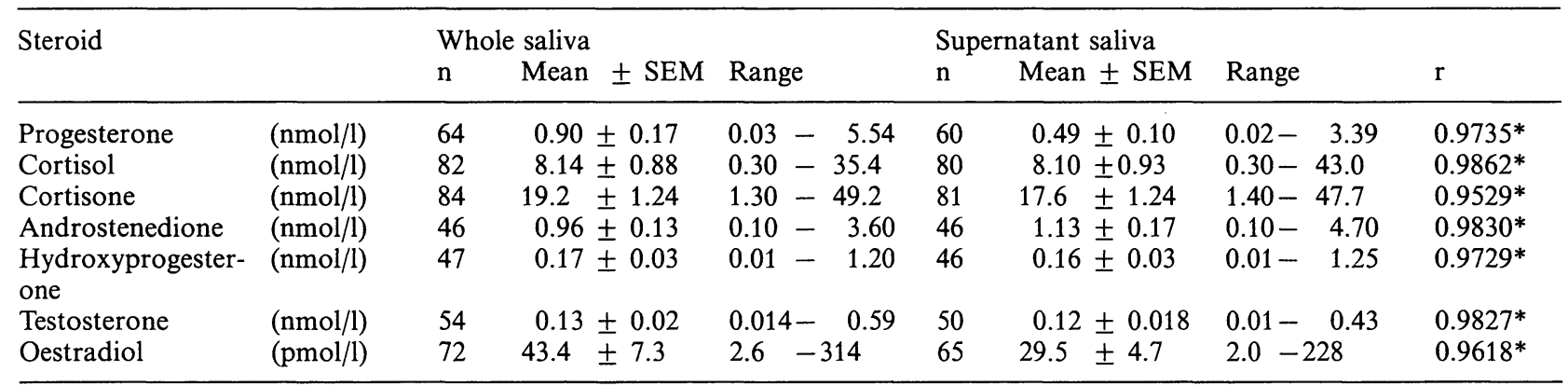

Tab. 4. Relative difference between whole saliva and supernatant saliva (mean $\pm \mathrm{SEM}$ ): $\mathrm{n}=$ number of subjects, $\mathrm{P}=$ probability of Wilcoxon signed rank test, ns $=$ not significant.

\begin{tabular}{llcc}
\hline Steroid & $\mathrm{n}$ & Increase $(\%)$ & $\mathrm{P}$ \\
\hline Progesterone & 59 & $36 \pm 0.06$ & $<0.0001$ \\
Cortisol & 80 & $-1 \pm 0.01$ & $\mathrm{~ns}$ \\
Cortisone & 81 & $10 \pm 0.02$ & $<0.0001$ \\
Androstenedione & 44 & $-4 \pm 0.03$ & $\mathrm{~ns}$ \\
Hydroxyprogesterone & 46 & $17 \pm 0.06$ & $<0.0025$ \\
Testosterone & 50 & $22 \pm 0.05$ & $<0.0001$ \\
Oestradiol & 56 & $49 \pm 0.15$ & 0.02 \\
\hline
\end{tabular}

oestradiol were higher in sonificated than in centrifuged saliva (increase $46 \pm 10 \%, \mathrm{p}<0.0001$ and $29 \pm 4 \%, \mathrm{p}<0.001$, respectively), whereas for the other steroids there was no significant difference. The values for oestradiol in non-pregnant female saliva, show differences between sonificated and centrifuged samples as similar to those observed in pregnancy samples; but this interpretation is preliminary, because despite very low sensitivity the levels approximate the detection limit of the assay. In male saliva the most striking difference between whole saliva and supernatant saliva was a decrease $(14 \pm 4 \%, \mathrm{p}<0.005)$ in androstenedione values after sonification of saliva, which was not observed for female non-pregnant saliva.

\section{Discussion}

The present study clearly demonstrates the effect of sample preparation on the concentrations of steroid hormones measured in saliva. In our study group as a whole, sonification of saliva yielded significantly higher levels of steroids than centrifugation, with the exception of cortisol and androstenedione. For these latter hormones the method of sample preparation had no influence on the results. Considering the groups of pregnant women, non-pregnant women and men separately, the most striking observation was a decrease in androstenedione concentrations in male saliva after sonification. It is possible that sonificating the saliva samples disperses some unknown sub- 

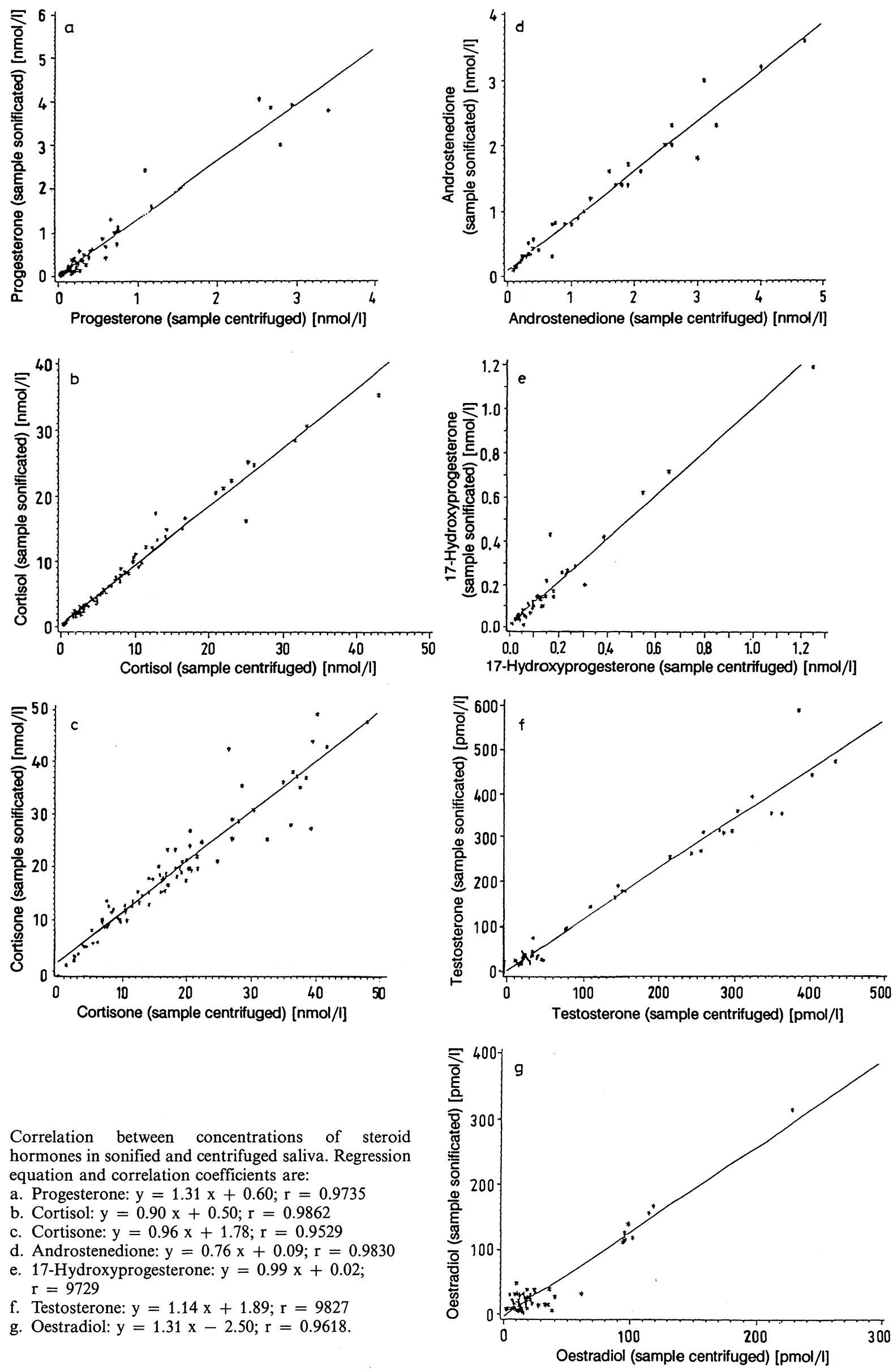

Fig. 1. Correlation between concentrations of steroid hormones in sonified and centrifuged saliva. Regression equation and correlation coefficients are:

a. Progesterone: $y=1.31 \mathrm{x}+0.60 ; \mathrm{r}=0.9735$

b. Cortisol: $\mathrm{y}=0.90 \mathrm{x}+0.50 ; \mathrm{r}=0.9862$

c. Cortisone: $\mathrm{y}=0.96 \mathrm{x}+1.78 ; \mathrm{r}=0.9529$

d. Androstenedione: $\mathrm{y}=0.76 \mathrm{x}+0.09 ; \mathrm{r}=0.9830$

e. 17-Hydroxyprogesterone: $\mathrm{y}=0.99 \mathrm{x}+0.02$; $r=9729$

f. Testosterone: $\mathrm{y}=1.14 \mathrm{x}+1.89 ; \mathrm{r}=9827$

g. Oestradiol: $\mathrm{y}=1.31 \mathrm{x}-2.50 ; \mathrm{r}=0.9618$. 
stance(s), which interferes in the RIA. It is worth mentioning the results of Baxendale et al. (1982) (4), who demonstrated a sex-dependent difference in salivary testosterone values when comparing chromatographed and direct assays.

In the non-pregnant and male groups the effect of sample preparation was rather similar to that in the study group as a whole. In contrast, in the pregnant group, sonification of saliva resulted in higher values only for progesterone and oestradiol. The data for progesterone are comparable to those of Lequin et al. (1986) (17) and indicate a loss of steroid hormone when saliva is centrifuged. It is possible that the pelleted debris of saliva contains most of the binding proteins, which are precipitated by the process of

\section{References}

1. Ferguson, D. B. (1984) Physiological considerations in th use of salivary steroid estimation for clinical investigations. In: Steroid hormones in saliva. Frontiers of oral physiology Vol. 5 (Kawamura, Y. \& Ferguson, D. B., eds.) pp. 1-20, Karger, Basel.

2. Vining, R. F. \& McGinley, R. A. (1985) Hormones in saliva. CRC Crit. Rev. Clin. Lab. Sci. 23, 95-145.

3. Meulenberg, P. M. M., Ross, H. A., Swinkels, L. J. M. W. \& Benraad, T. J. (1987) The effect of oral contraceptives on plasma-free and salivary cortisol and cortisone. Clin. Chim. Acta 165 , 379-385.

4. Baxendale, P. M., Jacobs, H. S. \& James, V. H. T. (1982) Salivary testosterone: relationship to unbound plasma testosterone in normal and hyperandrogenic women. Clin. Endocrinol. 16, 595-603.

5. Vining, R. F., McGinley, R. \& Rice, B. V. (1983) Saliva serum unconjugated estriol in assessing fetoplacental function. J. Clin. Endocrinol. Metab. 56, 454-460.

6. Meulenberg, P. M. M. \& Hofman, J. A. (1989) Salivary progesterone excellently reflects free and total progesterone in plasma during pregnancy. Clin. Chem. 35, 168-172.

7. Swinkels, L. J. M. W., Meulenberg, P. M. M., Ross, H. A. \& Benraad, Th. J. (1988) Salivary and plasma free testosterone and androstenedione in women using oral contraceptives containing desogestrel or levonorgestrel. Ann. Clin. Biochem. 25, 354-359.

8. Odlind, V. \& Johansson, E. D. B. (1981) Free norethisterone as reflected by saliva concentrations of norethisterone during oral contraceptive use. Acta Endocrinol. (Copenhagen) $98,470-476$.

9. Horning, M. G., Brown, L., Nowlin, J., Lertratanangkoon, K., Kellaway, P. \& Zion, T. E. (1977) Use of saliva in therapeutic drug monitoring. Clin. Chem. 23, 157-164.

10. Walker, R. F., Joyce, B. G., Dyas, J. \& Riad-Fahmy, D. (1982) Salivary cortisol: I. Monitoring changes in normal adrenal activity. In: Immunoassays of steroids in saliva (Read, G. F., Riad-Fahmy, D., Walker, R. F. \& Griffiths, K., eds.) pp. 308-316, Alpha Omega Publishing LTD, Cardiff.

11. Coffey, J. C. \& Crutchfield, W. C. (1977) In vitro metabolism of 4-androstene-3,17-dione by human submaxillary gland homogenates. J. Dent. Res. 56, 332-334.

12. AlAttar, T. M. A., Roth, G. D. \& Hugoson, A. (1973) Comparative metabolism of $4-{ }^{14} \mathrm{C}$-progesterone in normal and chronically inflamed human gingival tissue. J. Period. Res. 8, 79-85. freezing and thawing of saliva (23), whereas centrifugation leads to a further loss of such proteins (33).

Our findings indicate that caution is warranted in the interpretation of data from salivary steroid hormone determinations. If indeed specific steroid binding proteins are present in saliva (31) the question of whether the salivary hormone concentrations reflect the plasma free levels has to be re-openend. The question arises as to which of the analysed materials, whole saliva or supernatant saliva, gives a real indication of the plasma free level. Assuming that the decrease in steroid concentrations in supernatant saliva is caused by the removal of specific binding proteins, we tend to believe that the latter is the better candidate, despite lower absolute values for the steroid hormones.

13. Rudd, B. T., Brown, S., Matthew, P. M. \& Rayner, P. H. W. (1982) The development of a radioimmunoassay for measurement of prednisolone (total and free) in serum and saliva from asthmatic children. In: Immunoassays of steroids in saliva (Read, G. F., Riad-Fahmy, D., Walker, R. F. \& Griffiths, K., eds.) pp. 327-333, Alpha Omega Publishing LTD, Cardiff.

14. Wang, C., Wakelin, K., White, J. \& Wood, P. J. (1969) Salivary androgens in hirsutism: are they of use in routine evaluation? Ann. Clin. Biochem. 123, 590-595.

15. Katz, F. H. \& Shannon, I. L. (1969) Parotic fluid cortisol and cortisone. J. Clin. Invest. 48, 848-855.

16. Choe, J. K., Khan-Dawood, F. S. \& Dawood, M. Y. (1983) Progesterone and estradiol in the saliva and plasma during the menstrual cycle. Am. J. Obstet. Gynecol. 147, 557562 .

17. Lequin, R. M., Boogaard, A. van den, Vermeulen, J. \& Danhof, M. (1986) Progesterone in saliva: pitfalls and consequent implications for accuracy of the determination. Clin. Chem. 32, $831-834$.

18. Evans, J. J. (1986) Progesterone in saliva does not paralle unbound progesterone in plasma. Clin. Chem. 32, 542544.

19. Wellen, J. J., Smals, A. G. H., Rijken, J. C. W., Kloppenborg, P. W. C. \& Benraad, Th. J. (1985) Testosterone and 4-androstenedione in the saliva of patients with Klinefelter's syndrome. Clin. Endocrinol. 18, 51-59.

20. Shaw, M. A. (1985) Steroid binding in saliva. Clin. Chem $31,345-346$.

21. Lindsay, J. C. B., Meechan, J. G., Stephen, K. W. \& Beeley, J. A. (1978) Albumin concentrations in human saliva from individual glands. J. Dent. Res. 58, 1244 (Abstr. 93).

22. Smith, D. J., Taubman, M. A. \& King, W. F. (1987) Immunological features of minor salivary gland saliva. J. Clin. Immunol. 7, 449-455.

23. Costigan, D. C., Guyda, H. J. \& Posner, B. I. (1988) Free insulin-like growth factor I (IGF-I) and IGF-II in human saliva. J. Clin. Endocrinol. Metab. 66, 1014-1018.

24. Mattila, A-L., Perheentuba, J., Salmi, J. \& Viinika, L. (1987) Human epidermal growth factor concentrations in urine, but not in saliva and serum, depend on thyroid state Life Sci. 41, 2739-2747.

25. Deville de Periere, D., Buys-Hillaire, D., Fabre de Thierrens, C., Puech, R., Elkaim, G. \& Aranciba, S. (1988) Somatostatin-immunoreactive concentrations in human saliva and in the submandibular salivary glands of the rat. Possible sexual dependence in the human. J. Biol. Buccale $16,191-196$ 
26. Turkes, A. \& Groom, G. V. (1982) Peptides in saliva. In Immunoassays of steroids in saliva (Read, G. F., RiadFahmy, D., Walker, R. F. \& Griffiths, K., eds.) pp. 165173, Alpha Omega Publishing LTD, Cardiff.

27. Turkes, A., Pennington, G. \& Griffiths, K. (1984) Determination of human chorionic gonadotrophin (Beta subunit) in saliva and its role in trophoblastic diseases. Eur. J. Cancer Clin. Oncol. 20, 191-192.

28. Eckersall, P. D. \& Beeley, J. A. (1980) Crossed immunoelectrophoretic methods of separation of salivary proteins at physiological concentrations. In: Saliva and salivation. Adv. Physiol. Sci. Vol. 28 (Zelles, T., ed.) pp. $261-266$, Pergamon Press, Budapest.

29. Hammond, G. L. \& Langley, M. S. (1986) Identification and measurement of sex hormone binding globulin (SHBG) and corticosteroid binding globulin $(\mathrm{CBG})$ in human saliva. Acta Endocrinol. (Copenhagen) 112, 603-608.

30. Selby, C., Lobb, P. A. \& Jeffcoate, W. J. (1988) Sex hormone binding globulin in saliva. Clin. Endocrinol. 28, 1924.
31. Chu, F. W. \& Ekins, R. P. (1988) Detection of corticosteroid binding globulin in parotid fluids: evidence for the presence of both protein-bound and non-protein-bound (free) steroids in uncontaminated saliva. Acta Endocrinol. (Copenhagen) $119,56-60$.

32. Mavoungou, D., Nowaczynski, W., Nowaczynski, M., Wilkins, G. E., Fung, K. \& Crofton, N. E. (1986) Human salivary or plasma aldosterone- and dehydroepi-androsterone-binding glycoprotein induces hypertension in the rat. Clin. Physiol. Biochem. 4, 355-367.

33. Marshall, T. \& Williams, K. M. (1987) Electrophoresis indicates protein loss on centrifugation of whole saliva. Clin. Chem. 33, 1263-1264.

34. Smals, A. G. H., Pieters, G. F. F. M., Boers, G. H. J., Raemakers, J. M. M., Hermus, A. R. M. M., Benraad, Th. J. \& Kloppenborg, P. W. C. (1984) Differential effect of single high dose and divided small dose administration of human chorionic gonadotropin on Leydig cell steroidogenic desentization. J. Clin. Endocrinol. Metab. 58, 327-331.

Immuno Technology Service B. V.

Nieuweweg 172

NL-6603 BT Wychen 